\title{
NIEMCY O POLSCE I POLAKACH? O RÓŻNYCH POZIOMACH TRANSFERU TREŚCI KULTUROWYCH W ŚREDNIOWIECZU*
}

\begin{abstract}
Abstrakt: Artykuł omawia pracę Andrzeja Pleszczyńskiego dotyczącą przedstawienia obrazu Polski i jej mieszkańców nie tylko w historiografii, ale w ogóle w komunikatach pisanych i ikonograficznych powstałych w Niemczech od drugiej połowy X w. do 1370 r. Autor artykułu zwraca uwage na dyskusyjny charakter przyjętego przez Pleszczyńskiego założenia o istnieniu w badanym okresie dwóch spójnych narodów - niemieckiego i polskiego. Podkreśla, że część tekstów mogła powstać jako wyraz tożsamości regionalnej.
\end{abstract}

Słowa kluczowe: historiografia, ikonografia, hagiografia, średniowiecze, Niemcy, Polska, Cesarstwo, epika rycerska.
Abstract: The article discusses the book by Andrzej Pleszczyński on the image of Poland and its people presented not only in historiography, but also in all written and iconographic materials produced in Germany between the second half of the tenth century and 1370 . The article's author pays attention to the discursive character of Pleszczyński's assumption about the existence of two organized and cohesive nations in the analysed period - the German and the Polish one. He emphasizes that some of the texts could have been written as expression of the regional identity.

Keywords: historiography, hagiography, Middle, Ages, Germany, Poland, Holy Roman Empire, knightly epic.

Badania prowadzone dotychczas przez Autora recenzowanej książki dotyczyły analizy sposobu komunikowania się, głównie przez członków średniowiecznych elit władzy, ze szczególnym uwzględnieniem dziesięcio-dwunastowiecznych Czech oraz kulturowych relacji niemiecko-polskich ${ }^{1}$. Z tych zaintereso-

* Wokół pracy Andrzeja Pleszczyńskiego, Przekazy niemieckie o Polsce i jej mieszkańcach w okresie panowania Piastów, Wydawnictwo UMCS, Lublin 2016, ss. 247.

${ }^{1}$ Przywołajmy tylko monografie: A. Pleszczyński, Przestrzeń i polityka. Studium rezydencji władcy wcześniejszego średniowiecza. Przykład czeskiego Wyszehradu, Lublin 2000; 
wań wyrosła poprzednia monografia Pleszczyńskiego, która dotyczyła obrazu pierwszej monarchii Piastów w narracjach niemieckich kronikarzy X-XI w. ${ }^{2}$ Prezentowana praca jest rozszerzeniem podjętej wówczas tematyki. Rozszerzeniem tematycznym, bo dotyczy obrazu Polski i jej mieszkańców nie tylko w historiografii, ale w ogóle w komunikatach pisanych i ikonograficznych. Rozszerzenie dotyczy także chronologii, bo analizowana monografia obejmuje okres od drugiej połowy X w. do $1370 \mathrm{r}$. Jednocześnie analiza funkcjonowania żywych w obrębie świata informacji klisz narracyjnych jest punktem wyjścia do dalej idących wniosków. Jak pisze Autor: „Przedstawię tu [--] analizę wiadomości o naszym kraju i o jego mieszkańcach, jakie zostały utrwalone w różnego rodzaju przekazach powstałych w Niemczech w średniowieczu w okresie panowania Piastów. Ważnym zadaniem w kontekście prowadzonych dociekań stanie się też próba docierania do tła kulturowego i historycznego zauważanych stwierdzeń oraz wydobycia ich głębszego znaczenia oraz społecznych konsekwencji, czasem wykraczających poza średniowiecze" (s. 9). Te konsekwencje wydają się mieć według Autora bardzo bezpośrednie przełożenie na współczesne postrzeganie świata. „Sfera opinii o krajach i ludziach ma jednak wiele [--] aspektów. [--] z jednej strony wyznacza ona podstawy działań politycznych (własnych i obcych), z drugiej zaś wpływa na nastroje konsumenckie i przekłada się na chęć zakupu szeroko pojętych produktów - również kulturalnych [--]”. Ale przede wszystkim „świadomość istoty rzeczy i umiejętność odróżniania fałszu od prawdy w istniejących opiniach o własnej wspólnocie jest również dla niej samej ważna - opierając się na takiej wiedzy, można próbować coś zmienić i poprawić. Trwała niska samoocena potrafi działać destrukcyjnie, przeszkadzać w rozwoju i doskonaleniu się, podobnie zresztą jak zbyt wysoka, czy w ogóle każda fałszywa" (s. 9-10, podobnie s. 11-12). Zatem obok celów tradycyjnie rozumianych jako naukowe, Autor wskazuje na możliwe znaczenie społeczne prac historycznych, w tym zwłaszcza podejmujących tematykę analizy narracyjnych obrazów przeszłości. Skonstatujmy, że mimo pewnych wahań (niejasne określenie „badań dla samego poznania tzw. prawdy”, s. 9) w tych słowach Autor opowiada się za racjonalnością dążenia badacza do poznania prawdy o świecie i za możliwością przekazywania obrazu prawdy.

Wybór podstawy źródłowej analiz - infosfery średniowiecznych Niemiec wyrasta z przyjęcia przez Pleszczyńskiego modelu centrum ideowo-kulturowego (Europa porzymska i pokarolińska) i kulturowych peryferii społeczności Europy, do których zalicza Polskę. Niemcy zaś są dla niego pośrednikiem między tymi dwiema sferami, zawsze dla Polski istotnymi. W pewien nawias bierze Autor społeczności śląską i pomorską. Ta ostatnia praktycznie zostaje usunięta z pola jego

idem, Niemcy wobec pierwszej monarchii piastowskiej (963-1034). Narodziny stereotypu. Postrzeganie i cywilizacyjna klasyfikacja władców Polski i ich kraju, Lublin 2008 i zmieniona, poprawiona wersja: The Birth of a Stereotype. Polish Rulers and their Country in German Writings c. 1000 A.D., Boston-Leiden 2011.

2 A. Pleszczyński, Niemcy wobec pierwszej monarchii piastowskiej (963-1034). 
widzenia (brak jasnego przywiązania do Polski, ale i do niemieckiego obszaru kulturowego). Na Śląsku zaś - według Autora - „do XIV wieku utrzymywała się jeszcze świadomość przynależności do polskiego kręgu kulturowego", ale jednocześnie „pojawiały się utwory wyrażające niemiecki punkt widzenia - również te kreujące zewnętrzny ogląd polskości" (s. 12-13). W literackich, religijnych, historiograficznych i ikonograficznych przekazach z tych kręgów Autor pragnie odszukać i analizować dotyczące Polski i jej mieszkańców „struktury narracyjne przekazywane z pokolenia na pokolenie", nazywając je toposami (s. 13). Pragnie przy tym uniknąć tworzenia katalogu wzmianek, a skupić się właśnie na głównych, wydobytych z nich nurtach znaczeń i ich wewnętrznych relacjach, wewnętrznej logice (s. 17).

Tym założeniom została podporządkowana struktura pracy. Po wstępie metodologicznym Autor podejmuje szeroko rozumianą problematykę źródłoznawczą, określając kontekst pojawiania się w źródłach interesujących informacji (rozdział 1). Mocno podkreśla zmienny charakter więzi politycznych między władcami Polski i Niemiec, traktując ten fakt jako czynnik odgrywający decydującą rolę dla pojawiania się Polski w narracjach niemieckich (s. 22-39). Spośród źródeł możliwych do przeanalizowania skupia się głównie na źródłach historiograficznych i literackich oraz traktatach encyklopedycznych, pomija natomiast dokumenty, wzmiankuje ikonografię i kartografię (s. 39-46). W kolejnym rozdziale odnajdziemy rozważania dotyczące przedstawienia początków ludu Polaków i jego miejsca wśród innych społeczności świata. Ten rozdział rozpada się na dwie części. Pierwsza jest próbą rekonstrukcji wizji genezy Polaków i Polski podzielanej przez niemieckich uczonych i historiografów w kontekście posiadanego przez nich obrazu świata, opierającego się z kolei na antycznych narracjach opisujących społeczności na pograniczu Imperium Rzymskiego. Druga część dotyczy wizji położenia Polski w kontekście współczesnej pisarzom ekumeny, którą kształtowały dwie tendencje: włączająca i wyłączająca Polskę z szeroko rozumianej Germanii. Tu spośród źródeł kartograficznych Autor odwołuje się do mapy z Ebstorfu (s. 89-90).

Rozdział trzeci zawiera liczne analizy opowieści i cykli opowieści o wydarzeniach mających - lub rzekomo mających - miejsce w Polsce, względnie dotyczących Polaków, a przewijających się w infosferze niemieckiej do około połowy XIV w. Ten rozdział jest w większym stopniu chronologicznie skontekstualizowany, znajdziemy tu wiele wątków powstałych w wyniku połączenia różnych opowieści o Polsce i jej mieszkańcach żywych w narracjach niemieckich. Autor wydzielił w tym zakresie narracje o początkach Polski, pierwszej monarchii Piastów, o okresie od odbudowy państwa za Kazimierza Odnowiciela do schyłku XII w., wreszcie wzmianki o współczesnych wydarzeniach wiążących się z Polską w narracjach trzynasto-czternastowiecznych z terenów Niemiec. Ta część w największym stopniu składa się ze zbioru wzmianek, które Autor starał się umieścić we właściwym dla nich kontekście politycznym, intelektualnym i literackim. Zastosowana przez niego metoda utrudnia jednak wydobycie głównych linii - owych toposów - które kryją się w dziesiątkach szczegółowych 
informacji. Nie ułatwia tego zwłaszcza brak podsumowania zarówno poszczególnych podrozdziałów, jak i całej części pracy.

Ostatni, kluczowy rozdział poświęcił Autor określeniu ogólnego obrazu Polaków i ich kraju w przekazach niemieckich, przy czym starał się wskazać te opinie, które wyrastały z pewnych ogólnoeuropejskich klisz opowieści o sąsiadach i obcych (Polacy w kontekście toposu barbarzyńskości, ziemie Polski jako bogate i żyzne, cywilizowane przez przybyszów z zewnątrz, s. 173-189). Odejście od dominacji stereotypu w poglądach na cechy Polski i Polaków datuje na XIII w., gdy w wyniku szerszych kontaktów kulturowych związanych z migracją Niemców na wschód poszerzył się zakres wiedzy i kontekst zainteresowania wschodnim sąsiadem wśród elit Niemiec (s. 200-211). Pleszczyński wskazał, że przywiązanie do tradycyjnego, stereotypowego opisu Polski i Polaków jako barbarzyńców dominowało w literaturze historiograficznej, tworzonej przez autorów duchownych. Natomiast w kręgu epiki, czy szerzej - przekazów tworzonych przez świeckich na własny użytek - obraz Polaka miał bardziej neutralny, ewentualnie modyfikowany bieżącymi potrzebami politycznymi charakter. Zjawisko to nie dotyczyło jednak tylko Polski, lecz w ogóle obrazu wschodnich sąsiadów Niemiec w ówczesnej kulturze naszego zachodniego sąsiada (s. 209).

W podsumowaniu Autor, zbierając cząstkowe ustalenia dotyczące stereotypowych opinii o Polakach (barbarzyńskość, pochodzenie przodków Polaków spoza właściwej wspólnoty Europejczyków), starał się wskazać konsekwencje ich przekazywania w obrębie kultury niemieckiej i polskiej. Podkreśla destrukcyjne skutki ich trwania także w obrębie polskiej kultury, przejawiające się „kompleksem Europy" (s. 218-219). Sugeruje, że podtrzymywanie w refleksji historycznej przekonania o napływowym charakterze etnosu słowiańskiego ma swoje korzenie we wskazanych wyżej, stereotypowych opiniach o Polakach (s. 219). Książkę kończy apel: ,jak już zatem stwierdziłem we wstępie do niniejszej książki, jest sprawą elementarnego rozsądku każdej wspólnoty politycznej propagowanie własnej historii i dbanie o jej interpretację" (s. 220).

Spośród założonych przez Autora we wstępie do książki celów jej przygotowania, nie chciałbym oceniać wykazania powiązania między toposami żywymi w kulturze społeczności niemieckojęzycznych w średniowieczu a elementami współczesnych nam kultur. Autor nie przeprowadził w tym zakresie dowodu. Zaproponował natomiast zwięźle kilka możliwości interpretacyjnych wybranych fenomenów z różnych dziedzin, czasów i społecznego zakresu kultur w kontekście wniosków $z$ analiz treści średniowiecznych przekazów. Uznaję to za ciekawą propozycję, inspirację dla dalszych badań, które pomogłyby ustalić genealogię mentalności grup i społeczeństw. Inspirację, która wymyka się obecnie falsyfikacji.

Zauważmy przy tym, że zasadnicza treść pracy nieco odbiega od wstępnych deklaracji. Wbrew nim badacz skupił się na okresie drugiej połowy XIXIII w., pobieżnie jedynie dotknął wieku XIV w. W części wynika to z faktu, że książka jest kontynuacją pracy poświęconej niemieckiej kulturze X-XI w., w części - że rządy Władysława Łokietka i Kazimierza Wielkiego stworzyły 
radykalnie odmienną sytuację polityczną w relacjach niemiecko-polskich. A to skutkowało zmianą podejścia do Polski wśród zachodnich sąsiadów. Akceptując taką postawę Autora warto byłoby zaznaczyć ten wybór w tytule i założeniach badawczych. Pozwoliłoby to lepiej skontekstualizować przedmiot badań. Obecnie przyjęty sposób konstruowania narracji, w którym mikroanalizy wielu źródeł są bądź osnute wokół wskazanych toposów (barbarzyńska Północ, ziemia obcych - Ziemia Obiecana), bądź prowadzone autonomicznie, na pograniczu krytyki źródła i analizy wątków literackich (rozdział trzeci), utrudnia recepcję treści, ale przede wszystkim wniosków Autora. Ponieważ jednak te zostały w zasadzie zaprezentowane w „Zakończeniu”, czytelnik szukający syntetycznego spojrzenia na poruszaną tematykę może od niego zacząć lekturę książki, by następnie móc skupić uwagę na odpowiednich fragmentach wykładu.

Wśród przyjętych przez Autora wstępnych założeń trapią mnie jednak najbardziej nie te dotyczące konstrukcji, lecz samej treści. Dla tej ostatniej kluczowe znaczenie ma przyjęte przez Pleszczyńskiego założenie istnienia w całym interesującym okresie dwóch dużych, spójnych grup społecznych objętych więziami wspólnoty politycznej i kulturowej. Nazywa je zresztą wprost narodami (s. 37), w domyśle - niemieckim i polskim. To ujęcie według mnie mocno dyskusyjne dla całego okresu XI - pierwszej połowy XIV w. Ale równie mocno dyskusyjne jest uznanie wszystkich historiograficznych, literackich i lirycznych wypowiedzi powstałych - z grubsza - na obszarze Cesarstwa za wyraz oglądu dwóch „narodowych” grup. To bardzo daleko idąca generalizacja, pomijająca problem nie tylko nadawcy, ale i kontekstu i celu powstania poszczególnych wypowiedzi ${ }^{3}$. Uważam, że lepszym rozwiązaniem byłoby rozdzielenie w refleksji nad komunikującymi grupami i spisanymi formami tych dyskursów wspólnot etnicznych - jednoczonych więziami kulturowymi, w tym zwłaszcza poczuciem historycznej wspólnoty losów bez wyraźnego kontekstu struktury administracyjno-politycznej i granic terytorialnej identyfikacji - od grup politycznych, w których oba wyżej wspomniane wyznaczniki (administracja i terytorium) odgrywają kluczowe znaczenie ${ }^{4}$. Dzięki temu możliwe byłoby oddzielenie

3 Z kłopotliwego charakteru terminu „naród” w odniesieniu do średniowiecznych źródeł dziejopisarskich zdawał sobie sprawę Norbert Kersken, który z jednej strony opowiadał się za badaczami wydzielającymi wśród gatunków kronikarskich w średniowieczu Nationalgeschichte i Nationalgeschichtsschreibung, ale unikał wiązania ich z fenomenem „narodu” i dość niejasno wskazywał na możliwe niuanse rozumienia terminu Nation w jego przymiotnikowym użyciu. Ostatecznie definiował sam gatunek poprzez treść dzieł - opowieści obejmujące dzieje od początków ludów do czasów narratora - bez definiowania głównego, społecznego aktora tych narracji, i z odwołaniem do badań nad genezą „narodów” francuskiego i niemieckiego, zob. N. Kersken, Geschichtsschreibung im Europa der „nationes”. Nationalgeschichtliche Gesamtdarstellungen im Mittelalter, Köln-Weimar-Wien 1995 (Münstersche Historische Forschungen, t. 8), s. 4-11.

4 Trzeba jednak pamiętać, że od XIX w. przez całe minione stulecie początki „narodu" i jego definicja były przedmiotem niezliczonych dysput socjologów i politologów, 
dyskursu o charakterze kulturowym od terytorialno-politycznego wraz ze stosownym rozdzieleniem źródeł. W pierwszym typie akcentuje się treści konstytuujące wspólnotę etniczną, z którą identyfikuje się autor komunikatu, za pomocą obrazu analogicznej, opisywanej wspólnoty. Celem dla tego typu narracji jest zdefiniowanie i ugruntowanie tożsamości grupy „swoich”, która w równym stopniu jest grupą wyobrażoną - stwarzaną przez autora źródła, jak wspólnoty opisywane. W drugim przypadku - dyskursu terytorialno-politycznego - komunikat ma silny kontekst bieżący, polityczny - i to zarówno na poziomie państw, jak i regionów - w tym wspierający starania o utwierdzenie istnienia organizmów polityczno-społecznych, takich jak państwa i regiony, a w przypadku tych ostatnich także ich przekształcanie w trwałe jednostki o charakterze państw. Perspektywa polityczna lub kulturowa nie muszą być rozłączne, podobnie jak w obrębie dyskursu politycznego spojrzenie przez pryzmat regionu i państwa, i mogą pojawić się w tym samym typie źródła. Tym większe znaczenie głębszej refleksji źródłoznawczej dla uzyskania precyzyjnego wyniku: czyją i czego wizję śledzimy? jaki komunikat ją przekazuje?

Wybór narodowej perspektywy spojrzenia na grupy biorące udział w komunikacji i same narzędzia komunikacji (dziś źródła historyczne) dyktował Autorowi postrzeganie konkretnych problemów i wynikających z tego założenia dyskusyjnych rozstrzygnięć. Gdy Autor pisze o zmianie sytuacji w relacjach niemiecko-polskich w XIII w. wynikających z migracji Niemców na wschód, dodaje: „transfer wiedzy o naszym regionie nie był tak wielki, jak można byłoby się spodziewać po tej zmianie jakościowej w kontaktach pomiędzy narodami" (s. 36-37). Tymczasem mam wątpliwości, czy miały wówczas miejsce kontakty „między narodami”. Anachronizmem wydaje mi się tak daleko idące absolutyzowanie i upodmiotowienie wspólnoty narodowej w realiach środkowoeuropejskich XIII-XIV w. Migranci stykali się z autochtonami mówiącymi językiem polskim, ale akurat w tym momencie, w XIII w., było to zetknięcie z członkami konkretnych społeczności regionalnych i lokalnych - głównie śląska, ale także Wielkopolski, w mniejszym stopniu Małopolski. Co więcej, było to najczęściej zetknięcie kategorii osób niekoniecznie wpływających na tworzenie komunikatów o dużym, publicznym zasięgu. Rycerstwo uboższe i średniozamożne,

ale też mediewistów odwołujących się do ich ustaleń i szukających średniowiecznych korzeni tego historycznego zjawiska. I bez wątpienia celna jest uwaga Waltera Schlesingera, że w obliczu wielości głosów kluczowe znaczenie ma zdefiniowanie przedmiotu dyskusji, bowiem w ciągu wieków zmieniało się znaczenie słowa „naród” zob. W. Schlesinger, Die Entstehung der Nationen. Gedanken zu einem Forschungsprogramm, w: idem, Ausgewählte Aufsätze von..., 1965-1979, wyd. H. Patze, F. Schwind, Sigmaringen 1987 (Vorträge und Forschungen, t. 34), s. 131. O ścisłych relacjach, także genetycznych, między wspólnotami etnicznymi a narodem tak w perspektywie kulturowej, jak politycznej wielokrotnie pisał Anthony D. Smith, The Ethnic Origins of Nations, wyd. 3, Hoboken 1991 (polskie tłumaczenie: Etniczne źródła narodów, Kraków 2009) i tom podsumowujący jego refleksję nad relacjami między „etnicznością” i funkcjonowaniem „narodów”: idem, The Nation in History. Historiographical Debates about Ethnicity and Nationalism, Cambridge 2000. 
chłopi i mieszczanie w tym czasie mogli przesyłać opowieści o nowym miejscu zamieszkania do krewnych, ale właśnie w lokalnym kontekście. Czy dostrzegano bezpośredni związek między społecznościami regionalnymi i lokalnymi a Polską i Polakami? Czy zamieszkanie przez przybyszów w danym miejscu nie przekształcało regionów w „swoje”, zwłaszcza dla ich potomków, utrudniając podnoszenie opinii o otoczeniu do poziomu spotkania abstrakcyjnych narodów? Nie znajduję w tej kwestii oczywistych odpowiedzi, bowiem z jednej strony źródła - zwłaszcza dokumentowe - wypełniają zwroty mówiące o „ius theutonicale, Theotonicum", a w drugiej połowie XII w. przeciwstawia się przybyszów spoza Śląska mieszkającym tu Polakom. Ale jednocześnie studia nad relacjami przybyszów i mieszkańców na Śląsku w XIII w. wskazują, że nie dochodziło w nich do wyostrzania różnic i kreowania stereotypowych wizji całych grup społecznych, lecz do pragmatycznego określania cech konkretnych, lokalnych społeczności i ich członków w danym miejscu i czasie ${ }^{5}$.

Niejasne wyniki refleksji nad odrębnością regionów i społeczeństw regionalnych w kontekście relacji z zachodnim sąsiadem prowadzić mogą do niełatwych do przyjęcia rezultatów analiz szczegółowych, które Pleszczyński przeprowadził w odniesieniu do społeczności śląskich. Autor w zasadzie pominął w swojej narracji śląską Kronikę polska (schyłek XIII w.) spisaną najpewniej w opactwie w Lubiążu ${ }^{6}$ i w kilku miejscach przedstawiającą relacje niemiecko-polskie tak w dziejach Śląska, jak i Polski ${ }^{7}$. Praktycznie zrezygnował z analizy Księgi henrykowskiej (krótka wzmianka na s. 53), której obie części powstały pod piórem opatów cysterskiego Henrykowa, obu zanurzonych w kulturze niemieckojęzycznej i opisujących relacje z polskojęzycznymi mieszkańcami Śląska i majątku klasztornego ${ }^{8}$.

Natomiast stosunkowo szeroko Pleszczyński omówił funkcjonowanie relacji niemiecko-słowiańskich na Połabiu w czasach krucjat (s. 178-179, 192-194). Sporo miejsca poświęcił też analizie Versus lubenses, anonimowego utworu

${ }^{5}$ Zob. P. Górecki, Assimilation, Resistance, and Ethnic Group Formation in Medieval Poland. A European Paradigm?, w: Das Reich und Polen. Parallelen, Interaktionen und Formen der Akkulturation im hohen und späten Mittelalter, red. T. Wünsch, A. Patschovsky (współpraca), Ostfildern 2003 (Vorträge und Forschungen, t. 59), s. 447-476.

${ }^{6}$ Szerzej o tym pisze Wojciech Mrozowicz, Śląska „Kronika polska”. Wstęp do studium źródłoznawczego (cz. 1), w: Studia z historii średniowiecza, red. M. Goliński, Wrocław 2003 (Acta Universitatis Wratislaviensis. Historia 163), s. 105-128.

7 Zob. przykładowo rozważania w obu kronikach o fikcyjnej bitwie pod Studnicą (Rothkirch), B. Zientara, Konrad Kędzierzawy i bitwa pod Studnica, PH 70, 1979, 1, s. 27-55, czy znaczenie w śląskiej Kronice polskiej anegdoty o walkach Bolesława Krzywoustego z królem Henrykiem V, P. Wiszewski, Dlaczego cesarz został kuchcikiem, a Piastowie przestali być królami? Przyczynek źródłoznawczy z historii mentalności i polityki XIII-wiecznych Ślazaków, w: Klio viae et invia. Opuscula Marco Cetwiński dedicata, red. A. Odrzywolska-Kidawa, Warszawa 2010, s. 91-98.

${ }^{8}$ Zob. P. Wiszewski, The multi-ethnic character of medieval Silesian society and its influence on the region's cohesion (12th-15th centuries), w: The long formation of the Region Silesia (c. 1000-1526), red. P. Wiszewski, Wrocław 2013 (Cuius regio? Ideological and Territorial Cohesion of the Historical Region of Silesia [c. 1000-2000], t. 1), s. 183-186. 
z końca XIV w., powstałego najpewniej po 1370 r. ${ }^{9}$ i przedstawiającego początki cysterskiego opactwa w śląskim Lubiążu (s. 180-187). W tym ostatnim wypadku Autor przeprowadzał analizę źródła, traktując je jako zawierające elementy związane ze świadomością narodową. Jednocześnie akceptując tezy Siegfrieda Epperleina, widzącego w nim dość stereotypową w treści idealizację działalności mnichów u zarania fundacji, dokonaną przez ich następców w konwencie i na rzecz tego ostatniego ${ }^{10}$. Autor unika umieszczenia treści tego źródła w kontekście regionalnym - walki mnichów o precedencję wśród klasztorów śląskich i dążenia w tym celu do wykazania jak najdawniejszego pochodzenia, a także ich starań o uwolnienie od ingerencji Piastów jako potomków fundatora, księcia Bolesława Wysokiego ${ }^{11}$. Wbrew sądom Autora (s. 186-187) nie ma w Versus lubenses sugestii o podporządkowaniu Polski - Rzeszy. Jest natomiast dążenie do wykazania jak najdawniejszych, antycznych wręcz korzeni Lubiąża. Wtręt o Kazimierzu Odnowicielu jedynie pobocznie wiąże klasztor z ideą Polski, miał natomiast przede wszystkim dowieść, że powstał tu z jego fundacji klasztor benedyktynów - najdawniejszy ośrodek monastyczny na Śląsku. Dzięki fundacji tego samego władcy, którego uważano za fundatora biskupstwa wrocławskiego. Czy mnich dążył do podkreślenia w ten sposób relacji między śląskiem a Królestwem Polskim z XIV w.? Wątpię, autor pragnął raczej ukazać równoczesność genezy biskupstwa i życia zakonnego w Lubiążu. I niewątpliwie dla mnicha - autora Versus Lubenses - Ślązacy byli Polakami. Tyle że nie stanowili elementu binarnej wizji Śląska - niemiecko-polskiego. Kategoria etniczna została użyta w źródle wtórnie wobec zasadniczego rozróżnienia kategorii społecznych: mnisi - cała reszta społeczności. Treści narodowe nie miały tu większego znaczenia. To swoiste origo klasztorne miało bardzo konkretne cele pragmatyczne, z tego też punktu widzenia pokazywało wrastanie mnichów w lokalność - w społeczność Polaków, która stawała się dzięki nim i tylko dzięki nim bardziej cywilizowana. Poczucie wyższości mnicha, które można odczytać z tekstu, nie dotyczyło różnic narodowościowych czy politycznych, lecz pozycji

${ }^{9}$ Zob. W. Mrozowicz, Z dyskusji nad początkami klasztorów w średniowiecznej historiografii ślaskiej, w: Origines mundi, gentium et civitatum, red. S. Rosik, P. Wiszewski, Wrocław 2001 (Acta Universitatis Wratislaviensis. Historia 153), s. 178-179.

10 Poza cytowaną przez Pleszczyńskiego niemieckojęzyczną wersją pracy wschodnioniemieckiego historyka warto pamiętać o jej tłumaczeniu na język polski, S. Epperlein, Mit fundacyjny niemieckich klasztorów cysterskich a relacja mnicha lubiąskiego z XIV wieku, PH 58, 1967, 4, s. 587-604.

11 W.P. Könighaus, Die Zisterzienserabtei Leubus in Schlesien von ihrer Gründung bis zum Ende des 15. Jahrhunderts, Wiesbaden 2004, s. 294-295 (z odwołaniem do prac Oskara Górki) i cytowana wcześniej praca Wojciech Mrozowicza, Z dyskusji nad początkami klasztorów; P. Wiszewski, Zwischen Chor und Krypta. Die schlesischen Herzöge, Zisterzienser und Zisterzienserinnen im 12.-14. Jahrhundert, w: Adlige - Stifter - Mönche. Zum Verhältnis zwischen. Klöstern und mittelalterlichen Adel, red. N. Kruppa, Göttingen 2007 (Veröffentlichungen des Max-Planck-Instituts für Geschichte, t. 227; Studien zur Germania Sacra, t. 30), s. $225-260$. 
społecznej (także w obrębie grupy społecznej, jaką byli zakonnicy na Śląsku) i kulturowo-cywilizacyjnej. Wydaje się więc, że mamy tutaj do czynienia z narracją poświadczającą budowanie tożsamości lokalnej w kontekście świadomości istnienia wspólnoty etnicznej. Tylko i aż tyle.

Ten wniosek nie unieważnia konstatacji Autora dotyczących budowania swoistego wizerunku Polaków przez mnicha, dąży jedynie do ich niuansowania. I wskazania, że wiele relacji niemiecko-polskich mogło rozgrywać się na poziomie lokalnym i regionalnym, w odpowiednich kontekstach politycznych i w odniesieniu do wspólnot etnicznych (kulturowych), a nie narodowych (politycznych). W kontekstach lokalnych kategorie „narodowe” miały drugorzędne znaczenie - nawet jeśli wykorzystywano w nich stereotypowe klisze narracyjne jako poręczne narzędzia komunikacyjne. Aby jednak sprawdzić siłę - lub słabość - tych rozwiązań, warto byłoby sięgnąć do materiału dokumentowego, jako przekazującego elementy świata mentalnego osób w większej mierze wyczulonych na wiedzę lokalną (książęta i ich otoczenie, rycerze, mieszczanie), w mniejszym stopniu troszczących się o przekaz zgodny z topiką właściwą dla analizowanych kultur w ogóle ${ }^{12}$. Pleszczyński uniknął tej procedury, przyjmując, że na Śląsku „utrzymywała się jeszcze świadomość przynależności do polskiego kręgu kulturowego, ale jednocześnie pojawiały się utwory wyrażające niemiecki punkt widzenia - również te kreujące pewien zewnętrzny ogląd polskości" (s. 13).

Teza ta daje się obronić w odniesieniu do dziewiętnasto-dwudziestowiecznych historyków polskich, dążących do dowiedzenia przynależności regionu do polskiej wspólnoty kulturowej, bądź niemieckich, którzy z kolei pragnęli w oparciu o wybrane źródła dowodzić sięgającej średniowiecza wyższości Niemców nad Polakami ${ }^{13}$. Tyle że przeniesienie z czasu państw narodowych założenia o dominacji kategorii narodu w refleksji nad grupami społecznymi i postrzeganiem przez ich członków rzeczywistości w odniesieniu do średniowiecznych mieszkańców śląska jest mocno dyskusyjne. I wymagałoby szerszego uzasadnienia. Trudno przyjąć opinię, że Śląsk jednocześnie z jednej strony był do połowy XIV w. traktowany jako część Polski, zaś z drugiej - że „kraj ten jednak już w owym czasie tak mocno był zintegrowany z Rzeszą, że powstawały tam przekazy literackie i inne o ewidentnej przynależności do niemieckiego obiegu kulturowego" (s. 33). Po pierwsze dlatego, że Śląsk nigdy nie był zintegrowany z Rzeszą pod względem politycznym lub administracyjnym. Ścisłe relacje od

${ }^{12}$ Do ciekawych wniosków mogłoby doprowadzić śledzenie zmian chociażby w falsyfikatach dokumentów fundacyjnych opactwa w Lubiążu, zob. P. Wiszewski, Nowe jak stare, czyli o tradycjach z falsyfikatów lubiąskiego dokumentu fundacyjnego (XIII-XIV w.), w: Stare i nowe w średniowieczu. Pomiędzy innowacja a tradycją, red. S. Moździoch, Wrocław 2009 (Spotkania Bytomskie, t. 6), s. 411-427.

${ }^{13}$ Zob. w odniesieniu do Versus Lubenses uwagi Siegfrieda Epperleina, Zur Mittelalterforschung in der DDR - eine Reminiszenz, w: Mittelalterforschung nach der Wende 1989, red. M. Borgolte, München 1995, s. 65-66. 
połowy XIV w. łączyły go z Królestwem Czech, odkąd w 1348 r. stał się krajem Korony Czeskiej. Po drugie, przygotowanie komunikatów przez osoby niemieckojęzyczne zamieszkujące śląsk nie gwarantuje dominacji w nich narodowej perspektywy. Tę ostatnią trzeba byłoby też zdefiniować. I jeśli na przykładzie źródeł z pogranicza kulturowego ten problem rysuje się tak wyraźnie, to przecież podobne pytanie można by zadać w odniesieniu do źródeł z terenu właściwego Cesarstwa - czy saskie przekazy wyrażają opinię niemiecką, czy saską? Czy nie należałoby zastanowić się nad możliwością odrębności w postrzeganiu Polski i Polaków przez mieszkańców regionów nadgranicznych i tych żyjących w głębi Cesarstwa? Nie bez przyczyny najwięcej o Polsce w okresie największego zainteresowania dziejami tutejszych mieszkańców mieli do powiedzenia Widukind i Thietmar, a później - co naturalne - źródła związane ze społecznościami sąsiadującymi z księstwami piastowskimi. Zarzucenie perspektywy regionalnej i etnicznej na rzecz państwowej i narodowej w ramach podjętej przez Autora tematyki zdecydowanie upraszcza postępowanie badawcze. Wydaje się także - co jednak należałoby poddać dyskusji - że wnosi niebezpieczeństwo generalizacji wniosków i pominięcia istotnych zjawisk zachodzących na poziomie mniejszych niż hipotetyczny naród grup społecznych.

Pomimo przedstawionych wyżej polemicznych uwag, chciałbym podkreślić, że recenzowana książka należy do najciekawszych polskich publikacji mediewistycznych ostatnich lat. Dąży do zagłębienia się w świat transferu treści kulturowych, śledzi genealogie topiki opisującej Polaków w oczach zachodniego sąsiada. Bez wątpienia jest to praca warta lektury, pozwalająca zastanowić się nad korzyściami i ograniczeniami analizy skupionej na historiografii, uzupełnionej literaturą epicką, a dążącej do poznania struktur mentalnych w skali całych społeczeństw, a przynajmniej ich elit, przy założeniu dominacji perspektywy wspólnoty narodowej w kreowaniu mentalności mieszkańców średniowiecznych Niemiec. Skłania jednak także do refleksji nad strukturalnymi ramami komunikacji między grupami społecznymi w średniowieczu i konsekwencjami przyjęcia współczesnej perspektywy w przypadku analizy krążenia treści kulturowych.

\section{Streszczenie}

Prezentowana praca Andrzeja Pleszczyńskiego Przekazy niemieckie o Polsce i jej mieszakańcy w okresie panowania Piastów (Lublin 2016) dotyczy obrazu Polski i jej mieszkańców nie tylko w historiografii, ale w ogóle komunikatów pisanych i ikonograficznych powstałych w Niemczech od drugiej połowy X w. do $1370 \mathrm{r}$. W literackich, religijnych, historiograficznych $\mathrm{i}$ ikonograficznych przekazach z kręgu kultury niemieckiej Autor pragnie odszukać i analizować dotyczące Polski i jej mieszkańców „struktury narracyjne przekazywane z pokolenia na pokolenie”, nazywając je toposami. Pragnie przy tym uniknąć tworzenia katalogu wzmianek, a skupić się na głównych, wydobytych z nich nurtach znaczeń. Pleszczyńskiemu zależy na określeniu kontekstu powstania owych toposów, kulturowych i politycznych uwarunkowań 
determinujących ich znaczenie. Ostatecznie Autor wskazał, że przywiązanie do tradycyjnego, stereotypowego opisu Polski i Polaków jako barbarzyńców dominowało w literaturze historiograficznej, tworzonej przez autorów duchownych. Natomiast w kręgu epiki, czy szerzej - przekazów tworzonych przez świeckich na własny użytek - obraz Polaka miał bardziej neutralny, ewentualnie modyfikowany bieżącymi potrzebami politycznymi charakter. Podejmując dyskusję z ustaleniami Pleszczyńskiego autor artykułu recenzyjnego zwraca uwagę na przyjęte przez niego założenie istnienia w badanym okresie i wchodzenia w interakcje przede wszystkim dwóch spójnych społeczności - narodów - niemieckiego i polskiego. Tymczasem autor artykułu podkreśla, że część tekstów mogła powstać jako wyraz tożsamości regionalnej, a nawet lokalnej. Zawarte w nich sądy nie muszą oddawać świadomości „niemieckiej” o „Polakach”, ale jednej grupy mieszkańców danego regionu (Śląska) o drugiej. Bez odwoływania się do kategorii tożsamości narodowej. Mimo sformułowanych zastrzeżeń autor ocenia pracę bardzo wysoko pod względem przyjętej metodologii, oryginalności i wiarygodności przyjętych wniosków i uogólnień.

\section{Germans on Poland and Poles? On Various Levels of the Transfer of Cultural Content in the Middle Ages}

The book (Andrzej Pleszczyński, Przekazy niemieckie o Polsce i jej mieszakańcy w okresie panowania Piastów, Lublin 2016) deals with the image of Poland and its people presented not only in historiography, but also in all written and iconographic materials produced in Germany between the second half of the tenth century and 1370. In literary, religious, historiographic, and iconographic sources produced in the circle of German culture, the author looks for 'narrative structures passed down from generation to generation', which he calls toposes, in order to analyse them. However, he wants to avoid making a catalogue of references, focusing instead on their main symbolism. Pleszczyński seeks to uncover a context of emergence of these toposes, to reveal cultural and political circumstances determining their meanings. Finally, Pleszczyński indicated that the traditional image of Poles as barbarians dominated in texts written by ecclesiastical authors. In the circles of epics or, in a more broader sense, in texts written by lay people, the image of Poles was more neutral in character, modified by current political needs. Entering into a discussion with Pleszczyński's establishments, the author of the present text draws attention to Pleszczyński's assumption about the existence of two organized and cohesive societies-nations - the German and the Polish one, in the analysed period. He emphasises that some of the texts could have been written as expression of regional, or even local identity. Thus, it is possible that the texts do not reflect 'German' opinions about 'Polish people', but only opinions of one community inhabiting the region (Silesia) about another community of the same region - without referring to the category of national identity. Despite these reservations, the author greatly values the book as regards its methodology, originality, and reliability of its conclusions and generalizations. 


\section{Bibliografia}

Epperlein Siegfried, Mit fundacyjny niemieckich klasztorów cysterskich a relacja mnicha lubiaskiego z XIV wieku, PH 58, 1967, 4, s. 587-604.

Epperlein Siegfried, Zur Mittelalterforschung in der DDR - eine Reminiszenz, w: Mittelalterforschung nach der Wende 1989, red. Michael Borgolte, Oldenbourg Verlag, München 1995.

Górecki Piotr, Assimilation, Resistance, and Ethnic Group Formation in Medieval Poland. A European Paradigm?, w: Das Reich und Polen. Parallelen, Interaktionen und Formen der Akkulturation im hohen und späten Mittelalter, red. Thomas Wünsch, Alexander Patschovsky (współpraca), Jan Thorbecke Verlag, Ostfildern 2003 (Vorträge und Forschungen, t. 59).

Kersken Norbert, Geschichtsschreibung im Europa der „nationes”. Nationalgeschichtliche Gesamtdarstellungen im Mittelalter, Böhlau, Köln-Weimar-Wien 1995 (Münstersche Historische Forschungen, t. 8).

Könighaus Waldemar P., Die Zisterzienserabtei Leubus in Schlesien von ihrer Gründung bis zum Ende des 15. Jahrhunderts, Otto Harrassowitz Verlag, Wiesbaden 2004.

Mrozowicz Wojciech, Śląska „Kronika polska”. Wstęp do studium źródłoznawczego (cz. 1), w: Studia z historii średniowiecza, red. Mateusz Goliński, Wydawnictwo Uniwersytetu Wrocławskiego, Wrocław 2003 (Acta Universitatis Wratislaviensis. Historia 163).

Mrozowicz Wojciech, Z dyskusji nad początkami klasztorów w średniowiecznej historiografii ślasskiej, w: Origines mundi, gentium et civitatum, red. Stanisław Rosik, Przemysław Wiszewski, Wydawnictwo Uniwersytetu Wrocławskiego, Wrocław 2001 (Acta Universitatis Wratislaviensis. Historia 153).

Pleszczyński Andrzej, Niemcy wobec pierwszej monarchii piastowskiej (963-1034). Narodziny stereotypu. Postrzeganie i cywilizacyjna klasyfikacja władców Polski i ich kraju, Wydawnictwo UMCS, Lublin 2008 (wyd. ang.: The Birth of a Stereotype. Polish Rulers and their Country in German Writings c. 1000 A.D., Brill, Boston-Leiden 2011).

Pleszczyński Andrzej, Przekazy niemieckie o Polsce i jej mieszkańcach w okresie panowania Piastów, Wydawnictwo UMCS, Lublin 2016.

Pleszczyński Andrzej, Przestrzeń i polityka. Studium rezydencji władcy wcześniejszego średniowiecza. Przykład czeskiego Wyszehradu, Wydawnictwo UMCS, Lublin 2000.

Schlesinger Walter, Die Entstehung der Nationen. Gedanken zu einem Forschungsprogramm, w: idem, Ausgewählte Aufsätze von..., 1965-1979, wyd. Hans Patze, Fred Schwind, Jan Thorbecke Verlag, Sigmaringen 1987 (Vorträge und Forschungen, t. 34).

Smith Anthony D., The Ethnic Origins of Nations, wyd. 3, Wiley, Hoboken 1991 (polskie tłumaczenie: Etniczne źródła narodów, Wydawnictwo UJ, Kraków 2009).

Smith Anthony D., The Nation in History. Historiographical Debates about Ethnicity and Nationalism, Polity, Cambridge 2000.

Wiszewski Przemysław, Dlaczego cesarz został kuchcikiem, a Piastowie przestali być królami? Przyczynek źródłoznawczy z historii mentalności i polityki XIII-wiecznych Ślązaków, w: Klio viae et invia. Opuscula Marco Cetwiński dedicata, red. Anna Odrzywolska-Kidawa, DiG, Warszawa 2010. 
Wiszewski Przemysław, Nowe jak stare, czyli o tradycjach z falsyfikatów lubiaskiego dokumentu fundacyjnego (XIII-XIV w.), w: Stare i nowe w średniowieczu. Pomiędzy innowacja a tradycja, red. Sławomir Moździoch, IAiE PAN, Wrocław 2009 (Spotkania Bytomskie, t. 6).

Wiszewski Przemysław, The multi-ethnic character of medieval Silesian society and its influence on the region's cohesion (12th-15th centuries), w: The long formation of the Region Silesia (c. 1000-1526), red. Przemysław Wiszewski, eBooki.com.pl, Wrocław 2013 (Cuius regio? Ideological and Territorial Cohesion of the Historical Region of Silesia [c. 1000-2000], t. 1).

Wiszewski Przemysław, Zwischen Chor und Krypta. Die schlesischen Herzöge, Zisterzienser und Zisterzienserinnen im 12.-14. Jahrhundert, w: Adlige - Stifter - Mönche. Zum Verhältnis zwischen. Klöstern und mittelalterlichen Adel, red. Nathalie Kruppa, Vandenhoeck \& Ruprecht, Göttingen 2007 (Veröffentlichungen des Max-PlanckInstituts für Geschichte, t. 227; Studien zur Germania Sacra, t. 30).

Zientara Benedykt, Konrad Kędzierzawy i bitwa pod Studnica, PH 70, 1979, 1, s. 27-55.

Biog ram: Przemysław Wiszewski (nr ORCID: 0000-0003-2788-1445), prof. dr hab., mediewista i nowożytnik, zajmuje się wielokulturowością i wieloetnicznością średniowiecznych społeczeństw europejskich, dziejami Kościoła i religijności, historią Śląska, regionalistyką; kontakt: przemyslaw.wiszewski@uwr.edu.pl. 